\title{
The Impact of Capital Inflows on Asset Prices in Emerging Asian Economies: Is Too Much Money Chasing Too Little Good?*
}

August, 2008

Soyoung Kim
Korea University
Doo Yong Yang

ADB Institute

\begin{abstract}
In recent years, emerging Asian economies have experienced (i) large capital inflows, especially a surge in portfolio inflows, and (ii) an appreciation of asset prices such as stock price, land price, and nominal and real exchange rates. We empirically investigate the effects of capital inflows on asset prices by employing a panel VAR model. The empirical results suggest that capital inflows indeed contributed to the asset price appreciation in this region, although capital inflow shocks explain a relatively small part of asset price fluctuations.
\end{abstract}

Key words: Capital inflows, Asset prices, Panel VAR

JEL Classification: F32, F21, G12

\footnotetext{
* We thank Cindy Houser, Jong-Wha Lee, and Lei Lei Song for various suggestions, editing, and data construction. This research is supported by the research fund (R0600842) of Seoul Development Institute.

Department of Economics, Anam-Dong, Sungbuk-Gu, Seoul, Korea 136-701,e-mail: soyoungkim@korea.ac.kr.
} 


\section{Introduction}

The relationship between capital surges and domestic asset price boom is quite relevant in emerging market economies. Emerging market economies have frequently experienced a series of boom-bust cycles that result in economies crisis. It begins with a boom stage of credit expansion, investment increases, asset prices rise, and increasing capital inflows, and ends up with a burst stage when all reverses. The recent coincidence of huge capital inflows and asset price appreciation in Asia gives rise to a similar line of concerns. The policy options to mitigate the adverse effects of huge capital inflows are known to be relatively limited in Asia. Potential difficulties in policy options lie on complicated policy objectives, since there exists trade-offs between domestic and external objectives. ${ }^{1}$

Capital inflows in emerging Asian countries have reached $\$ 200$ billion in 2005, which is higher than the previous peak of $\$ 140$ billion in 1996, from \$26 billion in 1998. Observing this coincidence of rapid appreciation of asset and currency prices and huge capital inflows in recent years, policymakers and academia in the region have expressed concerns that huge capital inflows might be leading to financial instability and adverse consequences on the real economy. Given that financial market stability is critical to macroeconomic management, these trends have become significant factors affecting policy decisions in these emerging Asian economies.

The current surge in capital inflows, especially portfolio inflows in the region, may have been induced by both push factors related to the global environment, and pull factors related to post-crisis changes in the region's economic environment. With low interest rates and declining asset investment returns in advanced economies, investors' demand for investment opportunities in emerging market portfolio assets began to soar, fueled in part by the favorable global liquidity condition. At the same time, several economies in the region relaxed regulatory restrictions on

\footnotetext{
${ }^{1}$ For example, if monetary authorities target asset prices, the monetary policy in emerging Asia becomes more complicate since capital flows influence both exchange rates and domestic liquidity. This possibly affects asset prices. Monetary policy reacts to asset prices is highly controversial in general. See Roubini, (2006), Filardo (2004), Borio and Lowe (2002), Bordo and Jeanne (2002), Cecchetti et al (2002), and White (2006) for active monetary policy role in considering asset prices in its objectives. See also Miskin (2007), Schwartz (2002), Bernanke and Gertler (1999, 2001), Gilchrist and Leahy (2002), and Goodfriend (2003) for opponents of active monetary policy.
} 
foreign portfolio investments through capital market/account liberalization, further spurring massive portfolio inflows.

Capital inflows can help domestic economies in various ways, but large capital inflows may also produce undesirable macroeconomic outcomes. History tells us that emerging market economies often suffer periods of rapid capital inflows followed by outflows, generating boom-bust cycles. The initial period of capital inflows is often characterized by real exchange rate appreciation, domestic credit expansion, consumption and/or investment booms, and asset price bubbles. Over time, the process tends to reverse itself: net capital inflows turn into net outflows and boom turns into bust, with adverse consequences for local asset prices and, often, the real economy. In fact, several studies have shown that the Asian crisis in the 1990s was related to excessive capital flows. ${ }^{2}$ Then, as massive capital inflows and asset price appreciation are observed in the initial stage of boom-bust cycle, the recent coincidence of huge capital inflows and asset price appreciation in emerging Asian economies has raised concerns on the possibility of future crisis.

There are several channels that capital inflows may result in an increase in asset prices. First is a direct channel that affects the demand for assets, and then increases asset prices. In addition, there can be a spill-over effect to other financial markets such as real estate market subsequently. Second is a liquidity channel such that capital inflows may result in an increase in money supply and liquidity, unless fully sterilized, which in turn can boost the asset prices. Third, capital inflows tend to generate economic booms of the country, and then lead to an increase in asset prices.

However, recent asset price surge in emerging Asian market economies can be due to some other factors than capital inflows. For example, the recovery from the Asian Financial crisis and a better economic perspective of the Asian countries may have also led to asset price increases.

\footnotetext{
${ }^{2}$ Corsetti et al. (1998) points out that the causes of the crisis lie on financial over-lending, banking problems, and composition, maturity and size of capital inflows in Asia. Mishkin (1999) also asserts that the crisis started with financial liberalization that resulted in a lending boom which was fed by capital inflows, and bank lending expanded so rapidly that excessive risk-taking prevailed. Excessive bank lending to the real estate sector has also been noted. Sachs and Woo (2000) point out that too much money was poured into speculative real estate projects. Krugman (1998) also states that the problem began with financial institutions whose liabilities were perceived as having an implicit government guarantee, but were essentially unregulated and therefore subject to a severe moral hazard problem. The excessive risk lending of these institutions created increases in price, not of goods, but of financial assets.
} 
Monetary expansion and low interest rates of these Asian countries, originating from the recession in the late 1990s and early 2000s, may be another factor explaining the asset price booms. The exchange rate appreciation against the U.S. dollar may also be explained by the massive U.S. current account deficit and national debt problem.

On the other hand, some recent studies provide some interesting insights on asset bubbles and capital inflows. Caballero and Krishnamurthy (2006) argue that in emerging markets with shortage of stores of value and financial repression, dynamic inefficiency prevails and they are easy to create asset bubbles. They reproduce bubbles dynamics in emerging economies with capital flows; capital inflows increasing domestic liquidity during the growth phase of the bubble, but when the bubble crashes, capital flows reverse, domestic credit and investment falls. On the other hand, Ventura (2002) insists that bubbles act as a substitute for international capital flows, improving the international allocation of investment and reducing rate of return differentials across countries. These studies suggest that there can be asset price bubbles, even when foreign investors are not allowed to directly access domestic asset markets. Further, Ventura (2002) suggests that asset price appreciation can be observed in the economy without any capital inflows ${ }^{3}$.

To shed some light on these issues, we empirically investigate the effects of recent surges in capital inflows on appreciations of asset prices in emerging Asian economies. There have been some empirical studies on the effects of capital flows or capital account liberalization. Some studies discuss macroeconomic effects, for example, Kim, Kim, and Wang (2004), Montiel (1996), Agenor and Hoffmaister (1998), Corbo and Hernandez (1994), and Jansen (2003). However, there are not many studies that focused on the effects on asset prices. We examine whether the recent increase in asset prices is due to capital inflows, and if so, how much is due to capital flows. To discern the potential effects of these increase portfolio inflows and policy implications of these increased portfolio inflows, it is essential to assess their impact on the region's capital markets.

We construct panel VAR model to address the issue. First, VAR models are data-based with

\footnotetext{
${ }^{3}$ Refer to Tirole (1985).
} 
a relatively small number of restrictions. Such empirical framework is useful to document empirical facts. Second, the effects of capital inflows are expected to be inherently dynamic. For example, foreign capital inflows may affect different types of asset markets with different timings. VAR models are useful in inferring dynamic effects. Third, panel framework is used since the sample period under consideration is relatively short.

Section II summarizes trends in capital inflows to the region and asset prices and exchange rate, and discusses the potential effects of capital inflows on asset prices and exchange rates. Section III provides an empirical analysis on the effects of capital inflows and foreign portfolio inflows on asset prices using panel VAR models. Section IV provides a conclusion to this study.

\section{Recent Trends and Impacts of Capital Flows in Emerging Asian Economies ${ }^{4}$ II.1. Recent Trends in Capital Flows in Emerging Asian Economies}

For the last three decades, there have been large cross-border capital flows between economies on a global scale, and the trend has continued to the present. The profit-seeking activities and diversification of risks by domestic and multinational financial institutions contributed significantly to increasing cross-border capital flows. Furthermore, with the turn of the 1990s, capital inflows on a global scale started to take on diverse forms as investors from advanced economies diversified their assets internationally. Cross-border capital flows in general grew rapidly from the 1980s, because institutional investors began to show a high tendency to structure diversified portfolios in order to lower risks in their international portfolios. In addition, the development of information and communication technology enabled global investment and broadened opportunities for investors to manage risks though investment in diversified financial assets across various countries. Moreover, an increasing number of institutional investors, including insurance companies, pension funds, and hedge funds are investing in the emerging market. At the same time, global cyclical factors are also favorable in increasing cross-border capital flows in general, including lower interest rates and higher liquidity.

4 “Emerging Asian economies” refers to the People's Republic of China, Indonesia, the Republic of Korea, Malaysia, the Philippines, and Thailand, hereafter. 
Although cross-border capital flows have increased in general, Asia's emerging markets have been marked by a greater amount of capital inflows. First, economic fundamentals have improved significantly. Most crisis-hit countries have bounced back from the Asian crisis and in turn have lowered risk premiums combined with economic reforms in the region. Second, some currencies in the region are undervalued vis-à-vis the US dollar. Since there is an expectation of US dollar depreciation due to the current account deficit in the US, it seems safe to say that the undervalued currencies carry more weight in international portfolios, not only by regional investors but also by international investors as well. Third, many countries have loosened regulatory requirements on foreign portfolio inflows through capital liberalization. Taken together, these factors have contributed to a strong increase in inflows into the region's stock, bond, and real estate markets, although the magnitude of the impact varies across countries and markets, depending on local factors.

As a result of both push and pull factors as stated above, gross capital inflows in emerging Asian economies have reached $\$ 200$ billion in 2005, which is an increase of $100 \%$ over inflows in 1997 (see Figure 2) ${ }^{5}$. These inflows are close to 5\% of GDP, which is lower than 7\% of mid-1990s, but the trend is increasing (see Figure 1). China has been the main destination for these capital flows since 1993. In 1992, the share of China's capital inflows to the total capital inflows of these economies was 17\%, but it increased dramatically to 73\% in 2005 .

Figure 3 shows the patterns of capital inflows in these economies. FDI constitutes a major component in capital flows in these economies, accounting for $70 \%$ of total inflows. Since the early 1990s, FDI flows into East Asia have increased, especially concentrated in China and Southeast Asian countries. Debt financing had more weight than equity financing in the late 1980s; however, since the early 1990s, equity inflows have increased. Especially after the Asian crisis, equity inflows are increasing because most Asian economies have removed barriers to foreign investment on equity markets.

\footnotetext{
${ }^{5}$ Gross capital inflows are defined as nonresident investment of FDI, portfolio investment and other investments to emerging Asian economies.
} 
Gross capital outflows have increased rapidly in recent years and have reached an unprecedented level ${ }^{6}$. The emerging Asian economies’ capital outflows recorded over $\$ 130$ billion in 2005, which is $4 \%$ of GDP in these economies, an increase of close to $400 \%$ over the last 10 years. China's share of capital outflows constituted over $60 \%$ in 2005 , followed by Korea and Indonesia (see Figure 4 and 5).

Capital outflows are primarily composed of portfolio investments. In particular, bond outflows are the dominant pattern of capital outflows, comprising over $60 \%$ of the total outflows. This reflects a large proportion of Chinese and Korean banks' purchases of nonresident debt securities.

Broadening opportunities for foreign investment by institutional investors made available to private investors could constitute an important channel for the expansion of capital outflows. In 2006, China announced a set of measures to provide individual savers greater access to foreign assets. Qualified Domestic Institutional Investors now facilitate the foreign investment of domestic savings although the availability of such funds is currently limited. Korea also encourages more domestic individual investment abroad through mutual funds.

FDI outflows have increased as Asian firms have moved to establish global supply and sales networks. Outward FDI from China has grown rapidly. In Korea, FDI outflows have also increased as the country's leading automobile and electronics firms have expanded a sizable portion of their production overseas.

There are a couple of considerations with regard to the shift in the composition of capital flows to the region. The first is that the variability of overall flows may be a bit lower. In general, experience shows that FDI has been the least variable type of capital flow, while bank loans vary the most. Portfolio equity flows are nearly as variable as bank loans. However, as stock and bond market depth and liquidity increase, there is evidence that the volatility of FDI and debt securities flows may increase (Lipsey 1999, Albuquerque 2003). Second, there are important differences in

\footnotetext{
${ }^{6}$ Gross capital outflows refer to the total resident investment abroad including FDI, portfolio and other investment.
} 
the consequences of flow reversals. As compared with bank lending, FDI is less subject to sharp reversals. For portfolio investments in debt and equity markets, the direct impact of reversals is less likely to severely affect the economy because asset equity price adjustments will quickly reduce the BOP impact of sudden large outflows. There are, of course, potentially significant indirect transmission channels to the real economy - through wealth effects on spending and, more seriously, potential banking sector exposure to asset markets through securities holdings or through credit exposure to investors.

\section{II.2. Recent Trends in Asset Prices and Liquidity in Emerging Asian Economics}

There is a general tendency that asset price increases and exchange rates appreciate in emerging Asian economies. Figure 6 shows the equity prices for four ASEAN countries, China, and Korea. In these countries, stock prices increased sharply in recent years. From 2003, the upward trend in equity prices is very clear in most countries. In Indonesia, Korea, Philippines, and Malaysia, stock prices increased steadily from 2003. In China, a sharp increase started from mid 2005, and in Thailand, there was a big surge in 2003.

On the other hand, a downward trend in bond yields is found in recent years (Figure 7). In Indonesia and the Philippines, for example, drops in bond yields were quite substantial. In other countries, the decrease was more moderate. Note that the downward trend in bond yield only started from late 2005, which is later than the starting point of the upward trend in equity price. This might be due to the spillover effects from equity markets. Most foreign capital flows enter stock markets, partly because emerging East Asia has relatively less developed domestic bond markets and they are less open to foreign participation. However, as stock prices rise, expected returns on equities drop and bonds become more attractive to local investors, who bid up bond prices, lowering bond yields

In addition, land prices have increased in most countries (Figure 8). In Thailand and Indonesia, they have increased by more than 50\% from 2002. An upward trend has also been found in Korea from 2001. The land prices in the Philippines have also increased steadily.

Figures 9 and 10 show the nominal and real effective exchange rates, respectively. Recently, 
a clear appreciation trend is found in many countries, although the degree of appreciation varies across countries. The Korean won and the Thai baht appreciated steadily from 2003. Other currencies have appreciated from late 2005. The recent appreciation trend has also been found for the real effective exchange rates in all these countries. The real appreciation started from 2004 or 2005.

Table 1 shows the percentage changes in foreign exchange reserves. Foreign exchange reserves of these countries have increased rapidly in recent years. While these economies have been running sizeable amounts of surplus on their current accounts, they have also piled up large capital inflows. The bulk of the current account surpluses and capital inflows have been sterilized and added to their reserves, for these countries want to stabilize either the nominal or real effective exchange rate with the objective of maintaining their export competitiveness. Although the sterilization of reserve accumulation was substantial, money supply (M2) also tended to increase sharply in some countries, which may imply that the sterilization was only partial.

\section{II.3. Effects of Portfolio Inflows on Capital Markets}

Capital inflows may result in an increase in asset prices and an appreciation of the nominal and real exchange rates. We summarize the main mechanisms in this section. Capital inflows can affect asset prices in three ways. First, foreign portfolio inflows can directly affect the demand for assets. For example, capital inflows to the stock market increase the demand for stocks and increase the stock price. In addition, portfolio inflows may affect other markets subsequently. For example, as capital flows into the stock market, the stock price increases but the expected return on stocks may decrease. Then, investors may seek higher returns on other asset markets, such as the real estate market and the bond market, and give upward pressure on other asset prices.

Second, capital inflows may result in an increase in money supply and liquidity, which in turn may boost the asset prices. Capital inflows tend to appreciate the nominal and real exchange rates. To avoid exchange rate appreciation, monetary authorities must intervene in the foreign exchange market. Monetary authorities cope with excess demand for local currency (due to capital 
inflows) by buying foreign currencies following capital inflows. This results in an accumulation of foreign exchange reserves and, accordingly, domestic money supply. When this leads to an increase in liquidity flows into asset markets, asset prices may surge. The foreign exchange intervention may be sterilized by selling government securities through an open market operation. However, if sterilization is partial, then liquidity and asset prices may increase.

Third, capital inflows tend to generate economic booms in a country and lead to an increase in asset prices. Past studies have documented economic booms often following capital inflows. Monetary expansion following capital inflows may lead to economic booms. Capital inflows due to a fall in the world interest rate may lead to consumption booms and investment booms. A lowering world interest rate would also decrease the domestic interest rate, which may lead to investment booms. For a debtor country, a fall in the world interest rate will induce income and substitution effects, which may lead to consumption booms.

Capital inflows tend to appreciate nominal and real exchange rates. In a floating exchange rate regime, foreign portfolio inflows would directly affect the demand for domestic currency assets, which leads to appreciation in the nominal exchange rate. Combined with sticky prices, the real exchange rate can also appreciate. On the other hand, if the monetary authority intervenes in the foreign exchange market, then the nominal appreciation may be avoided in a managed floating regime. However, the real exchange rate may still appreciate. As discussed, consumption and investment booms are likely to increase the price of non-traded goods more than the price of traded goods because the supply of non-traded goods is more limited than the supply of traded goods.

As evidenced by the concurrent surges in portfolio inflows, asset price increases, and exchange rate appreciation in the data, there may be substance to the assertion that a recent surge in portfolio inflows increased asset prices and added to appreciation pressure rates. Furthermore, there was an increase in money supplies, despite a substantial sterilization of foreign exchange reserve accumulation.

However, other factors may explain asset price increases and exchange rate appreciation in 
the Asian countries. The recovery from the Asian Financial crisis and a better economic perspective of the Asian countries may have also led to asset price increases. Monetary expansion and low interest rates of these Asian countries, originating from the recession in the late 1990s and early 2000s, may be another factor explaining the asset price booms that these countries have experienced. The exchange rate appreciation against the U.S. dollar may also be explained by many other factors. For example, the massive U.S. current account deficit and national debt problem may have also caused the depreciation of the U.S. dollar. In the following section, we try to formally assess the effects of portfolio inflows on asset prices and exchange rates.

\section{Empirical Analysis}

\section{III.1. Panel VAR Model}

We examine the effects of foreign capital inflows on asset prices using panel VAR (Vector Auto-Regression) models. VAR models provide useful methodology to investigate this issue. First, VAR models are data-based with a relatively small number of restrictions. Such empirical framework is useful to document empirical facts. Second, the effects are expected to be inherently dynamic. For example, foreign capital inflows may affect different types of asset markets with different timings. VAR models are useful in inferring dynamic effects. Third, panel framework is used since the sample period under consideration is relatively short.

Let's assume that an economy $i$ is described by the following structural form equation:

$$
G(L) y_{t}^{i}=d^{i}+e_{t}^{i}
$$

where $G(L)$ is a matrix polynomial in the lag operator $L, y_{t}^{i}$ is an $m \times 1$ data vector, $d^{i}$ is an $m \times 1$ constant matrix, $\mathrm{m}$ is the number of variables in the model, and $e_{t}^{i}$ denotes a vector of structural disturbances. By assuming that structural disturbances are mutually uncorrelated, $\operatorname{var}\left(e_{t}^{i}\right)$ can be denoted by $\Lambda$, which is a diagonal matrix where diagonal elements are the variances of structural disturbances. The individual fixed effect, $d^{i}$, is introduced to control for the country specific factors that are not included in the model but affect each variable. 
We pooled the data and estimated the following reduced form panel VAR with the individual fixed effect:

$$
y_{t}^{i}=c^{i}+B(L) y_{t-1}^{i}+u_{t}^{i},
$$

where $c^{i}$ is an $m \times 1$ constant matrix, $B(L)$ is a matrix polynomial in the lag operator $L$, and $\operatorname{var}\left(u_{t}^{i}\right)=\Sigma$

There are several ways of recovering the parameters in the structural form equation from the estimated parameters in the reduced form equation. The identification schemes under consideration impose recursive zero restrictions on contemporaneous structural parameters by applying Cholesky decomposition to the reduced form residuals, $\Lambda$, as in Sims (1980). Note that our statistical inference is not affected by the presence of non-stationary factors since we follow a Bayesian inference (see Sims 1988 and Sims and Uhlig 1991). ${ }^{7}$

\section{III.2. Empirical Model}

In the basic model, the data vector, $y_{t}^{i}$, is $\{\mathrm{Y}, \mathrm{P}, \mathrm{CAP}, \mathrm{SP}, \mathrm{LP}\}$ where $\mathrm{Y}$ is output, $\mathrm{P}$ is the log of the price level, CAP is capital inflows or portfolio inflows (as a ratio to trend GDP), SP is the $\log$ of the stock price and LP is the log of the land price. ${ }^{8}$ We included CAP, SP, and LP since they are the main variables of our interests. $\mathrm{Y}$ and $\mathrm{P}$ are included to control for the factors that can affect asset prices.

The factors or variables affecting domestic asset prices can be divided into three types. First, certain factors affect domestic asset prices mostly through changes in foreign capital inflows. For example, a change in the foreign interest rate changes foreign capital inflows and thereby affects domestic asset price. Second, certain factors affect domestic asset prices mostly through channels other than foreign capital inflows. For example, an increase in the price level (which may be the result of monetary expansion) may increase domestic asset prices, but in this transmission, foreign capital inflows are not likely to play an important role. Third, there are certain factors that affect

\footnotetext{
${ }^{7}$ Specifically, we generate the standard error bands based on a Bayesian method, as described in RATS Manual. We also experimented with the difference specifications of Y, P, SP, and LP. Results do not change qualitatively.

8 A linear trend in GDP is assumed. Assuming different types of trend such as quadratic trend do not affect the results much. 
domestic asset prices not only through changes in foreign capital flows but also through other channels. For example, a change in the domestic economic condition induces foreign capital inflows and then affects the asset prices. But a change in the domestic economic condition also influences investments by domestic investors and thereby affects asset prices.

In the basic model, we control for the second and the third types of factors to analyze the effects of capital inflows on asset prices. We include the second type of factor in the model because there may be an omitted variable bias if an important factor is not included in the model. We also include the third type of factor in the basic model. If we exclude this type of factor in the model, then all the effects of this factor, including the effects through channels other than changes in capital inflows, may be captured as the effects of foreign portfolio inflows. On the other hand, the first type of factor affects the asset prices mainly through the changes in capital inflows. Therefore, to analyze the effects of capital inflows, it is unnecessary to include this type of factor in the model.

Aggregate output is the most important variable that represents the domestic economic condition, which may affect asset prices both through changes in foreign capital inflows and through other channels (the third type). The aggregate price level shows the nominal and monetary condition of the economy, which can also affect asset prices (the second type).

Regarding the ordering of the variables, aggregate output and aggregate price level are assumed to be contemporaneously exogenous to other financial variables in the system. The underlying idea is that real economic activities and the aggregate price level respond to changes in economic condition sluggishly but the financial sector reflects all the information immediately. This type of identifying assumptions are suggested by Sims and Zha (2006), and widely used in other studies such as Kim (1999) and Kim and Roubini (2000).

In addition, by ordering the aggregate output and the price level before capital inflows, structural shocks to capital inflows are constructed as conditioned on the current (and lagged) aggregate output and the price level. Given that we would like to control for those variables in identifying structural shocks to capital flows, this ordering is ideal for our purpose. 
On the other hand, capital inflows are assumed to be contemporaneously exogenous to asset prices. This type of assumption is used by Kim, Kim, and Wang (2004) and Froot, O’Connell, and Seasholes (2001). In principle, stock prices can affect foreign portfolio inflows. High past returns may signal high future returns when momentum is an important determinant of expected return. Therefore, high past returns may induce foreign portfolio inflows. However, even in momentum trading, a very transitory change in asset prices is not likely to significantly affect foreign portfolio inflows. Therefore, the assumption of contemporaneous exogeneity of foreign portfolio inflows to stock price may be justifiable. On the other hand, there is not much foreign capital that directly flows into the real estate market in these economies. Therefore, the case of momentum trading is not particularly applicable to the case of land price, and the assumption of contemporaneous exogeneity of foreign portfolio inflows to land price is reasonable.

In order to make the assumption on stock price more reliable, the data on stock price is constructed as the end of the period value. ${ }^{9}$ Consequently, capital inflows are a flow variable that represents the activities during the period while stock price represents the value at the end of period. Therefore, the assumption that other variables such as capital inflows are contemporaneously exogenous to stock price is a reasonable one.

Finally, notice that the ordering between $\mathrm{Y}$ and $\mathrm{P}$ and between asset prices does not matter when we examine the effects of shocks to capital inflows. ${ }^{10}$

In addition, we have constructed various extended models. First, we have considered some extended models with other factors that may affect asset prices through channels other than capital inflows. The extended model is: $\{\mathrm{Y}, \mathrm{P}, \mathrm{X}, \mathrm{CAP}, \mathrm{SP}, \mathrm{LP}\}$, where $\mathrm{X}$ is a new variable. We order $\mathrm{X}$ before CAP to control for both current and lagged factors in identifying structural shocks to capital flows. We consider the domestic short-term interest rate and capital outflows. Low domestic interest rate may increase asset prices while capital outflows may decrease asset prices.

Second, to examine the effects on other relevant variables such as the nominal and real

\footnotetext{
${ }^{9}$ Using daily stock price data, the stock price at the last date during the quarter is constructed.

${ }^{10}$ Refer to Christiano, Eichenbaum, and Evans (1999).
} 
effective exchange rates, we have added a new variable to the basic model. Since it is not clear whether capital inflows are contemporaneously exogenous to exchange rates (and vice versa), we consider two types of models with different orderings: $\{\mathrm{Y}, \mathrm{P}, \mathrm{X}, \mathrm{CAP}, \mathrm{SP}, \mathrm{LP}\}$ and $\{\mathrm{Y}, \mathrm{P}, \mathrm{CAP}, \mathrm{X}$, SP, LP\}, where $\mathrm{X}$ is the nominal or real effective exchange rates.

We consider five countries in our model: South Korea, Malaysia, Indonesia, the Philippines, and Thailand. ${ }^{11}$ The estimation period is from the first quarter of 1999 to the first quarter of 2006. Quarterly data is used. ${ }^{12}$ We exclude the period prior to 1999 since economic behavior before and after the Asian crisis may be considered inconsistent within the framework of our study. A constant term and four lags are assumed.

All data series have been obtained from International Financial Statistics, with the exception of stock prices, land prices and nominal and real effective exchange rates. Stock price has been obtained from Bloomberg while nominal and real effective exchange rate has been obtained from BIS. Land prices have been obtained from various sources - the Bank of Korea webpage (for Korea), ADB (for Philippines), and Gochoco-Bautista (2007) (for the others).

\section{III.3. Empirical Results}

Figures 11 and 12 report the impulse responses of each variable with one standard error band (68\% probability bands) per 10 quarter horizon. The names of shocks are reported at the top of the graph in each column. The names of responding variables are reported at the far left of the graph in each row. Figure 11 shows the results for the system including capital inflows while Figure 12 reports the results for the system including portfolio inflows.

Although we are mostly interested in the effects of capital inflow shocks and other shocks do not have much structural interpretation, we provide some explanations on the effects of other shocks to understand the general picture. Positive shocks to RGDP and PGDP tend to increase the asset prices over time. PGDP shocks have a very strong effect on asset prices while RGDP shocks have a weak effect. We included these two factors in order to control for the factors that affect asset

\footnotetext{
11 Enough data series are not available for other countries.

12 Some variables such as capital inflows are not available in monthly frequency. 
prices possibly through channels other than portfolio inflows. Since we have found that these factors indeed affect asset prices significantly, we may say that at least some factors are controlled. On the other hand, these two shocks do not seem to affect capital flows or portfolio flows strongly. Therefore, we may infer that these two shocks affect asset prices without changing capital inflows much, that is, mostly through channels other than capital inflows.

Then, we examine the effect of a positive shock to capital flows, which is of our main interests. To infer the nature of capital flow shocks, first we can see the responses of capital flows. Capital flows increase by $4 \%$ of trend GDP on impact. In the next quarter, the surge in capital flows decrease, but still capital flows increase by about $0.6 \%$ of trend GDP, and this modest surge continues over the next two years or so.

In response to capital flow shocks, the stock price increases for three quarters. The increase in stock price is about $2-3 \%$ for the first three quarters. The land price also increases, but in general the increase is more delayed than the increase in stock price. Land price increases about $1 \%$ on impact, and it further increases up to three quarterly after the shock, and then decreases back to the initial level. The maximum effect of the $1.5 \%$ increase is found in the $3^{\text {rd }}$ quarter after the shock.

The effect of portfolio inflows on asset prices is similar on the whole, but the effect seems to be weaker. Stock price increases on impact by about $1.5 \%$, and decreases back to the initial level in three quarters. The land price increase is delayed, and the maximum effect, about $1 \%$ increase, is found in about five or six quarters after the shock. These weaker effects seem to be related to the nature of portfolio inflow shocks. Portfolio inflows increase at about $2.5 \%$ on impact and decreases back to the initial level in the next period. That is, shocks to portfolio inflows are smaller and less persistent, which may explain why the effects of portfolio inflows shocks on asset prices are weaker than those of capital inflows.

It is also interesting that neither capital inflow shocks nor portfolio inflow shocks affect domestic output and price much; the responses of output and price level are not significantly different from zero with $68 \%$ probability. Finally, positive shocks to asset prices increase capital 
inflows and portfolio inflows, although the effect is not particularly strong. Increasing asset prices may attract foreign investors and induce capital inflows.

To further confirm the above results, we report the results from extended models that additionally include domestic short-term interest rate or capital (or portfolio) outflows in Figure 13. Figure 13 shows the effects of capital inflows (or portfolio inflows) shocks on capital inflows (or portfolio inflows), stock prices, and land prices. 'CAP-R,' 'CAP-OUT,' 'PORT-R,' and 'PORTOUT' stands for the model with capital inflows and short-term interest rates, the model with capital inflows and capital outflows, the model with portfolio inflows and short-term interest rates, and the model with portfolio inflows and portfolio outflows. In these models, the results are qualitatively similar to those of the basic five variable model.

Then, we report the effects of capital inflow (and portfolio inflow) shocks on the real and nominal effective exchange rates, using the extended model that additionally includes the real or nominal effective exchange rates in Figure 14. The name of the type of shocks (either capital inflows shocks or portfolio inflows shocks) and the name of the responding variable (either NEER nominal effective exchange rate - or REER - real effective exchange rate) and the structure of the model ("exog” indicates the model in which exchange rate is contemporaneously exogenous to capital inflows - otherwise, the model in which capital inflows is contemporaneously exogenous to exchange rate) are defined at the top of each graph.

Positive capital inflow shocks lead to real and nominal appreciation, which is different from zero with $68 \%$ probability in all specifications. The effects of portfolio inflow shocks are weaker, but nominal and real exchange rates tend to appreciate in all cases. Also, note that in most cases, the responses of the nominal effective exchange rates are very similar to those of the real effective exchange rates, which suggests that real appreciation is mostly induced by nominal appreciation.

In summary, a surge in capital inflows or portfolio inflows has positive effects on asset prices. Stock price increases immediately as capital inflows directly hit the stock market. The land price increase is more delayed, which may be explained by a spill over effect. The real effective 
exchange rate appreciates, which is mostly explained by a nominal appreciation. However, the effects of capital inflows on the macro-economy seem to be limited, showing that output and the aggregate price level do not respond much.

Next, we further inquire into to what extent variation in asset prices are explained by capital inflow shocks by applying forecast error variance decomposition to asset prices. Table 3 reports the results for the basic empirical models. Portfolio inflow shocks explain no more than $5 \%$ of stock price and land price fluctuations in any horizon within 8 quarters. The contribution of capital inflow shocks is larger, but still not very significant. Capital inflow shocks explain less than $8 \%$ of stock price fluctuations in any horizon within 8 quarters. They explain less than $14 \%$ of land price fluctuations in any horizon within 8 quarters as well. Based on these results, although capital inflows affect asset prices significantly, it might be difficult to argue that the recent asset price surge in these emerging Asian countries is mostly due to the recent increase in capital inflows. ${ }^{13}$

Finally, we find that capital inflows surge in these emerging Asian countries, and the empirical results suggest that capital inflow shocks do have some responsibility for the rise in asset prices in recent years. Therefore, the next question is whether the current surge in capital flows may ultimately destabilize the macro-economy as we have seen historically, for example, during the Asian crisis in the late 1990s. In this regard, we may say that a devastating crisis is less likely to occur in upcoming years compared to the late 1990s, although we cannot entirely exclude the possibility. First, the nature of the capital inflows is different. In the 1990s, a large portion of the surge in capital inflows was short-term debt, but an increase in foreign portfolio inflows is a major part in recent years. Second, the exchange rate had been more tightly controlled in the 1990s, but these countries have adopted more flexible exchange rate arrangements after crisis. Third, these countries (e.g., China and Korea) have built up massive foreign exchange reserves, and a regional cooperation system has been arranged since the Asian crisis. Fourth, banking and financial sectors

\footnotetext{
${ }^{13}$ However, the estimation period does not include the most recent dates when asset price appreciation accelerated and serious concerns on capital flows emerged. If a more recent period is included, the role of capital flow shocks might increase. In addition, whatever the exact contribution of capital inflow shocks to variations in asset prices, policymakers should pay attention to current asset price increases since it has been very rapid in recent years. 
have been strengthened and there have been quite a few structural reforms in these countries. In addition, our empirical results also show that capital inflow shocks do not significantly boost the macro-economy, which may imply that the boom-bust cycle theory is less likely to be applied in the current case. ${ }^{14}$

\section{Conclusions}

In recent years, emerging Asian economics experienced (i) large capital inflows, especially a surge in portfolio inflows, and (ii) an appreciation of asset prices such as stock prices, land prices, and nominal and real exchange rates. We first documented the recent trend in capital inflows and asset prices in these countries, and reviewed how a surge in capital inflows can increase asset prices.

Emerging economies in Asia are using a variety of policy measures to deal with large capital inflows and asset price hikes, including mitigating currency appreciation pressure by implementing sterilization measures, encouraging capital outflows, and tightening credit growth by increases in lending rates and required reserves. However, potential difficulties in policy options lie on complicated policy objectives, since there exists trade-offs between domestic and external objectives. Most Asian economies have taken the export-oriented growth strategy. Nominal (or real) exchange rates are so important to keep export price competitive advantages. Under these circumstances, massive sterilization is necessary. However, the fact that not only the sterilization is partial, but also the increasing opportunity cost of sterilization brings about increasing liquidity in domestic markets, which might contribute to asset price hikes. If monetary authorities target asset prices, the monetary policy in emerging Asia becomes more complicate since capital flows influence both exchange rates and domestic liquidity, which in turn possibly affects asset prices.

In order to shed some light on these issues, we empirically investigated the effects of capital inflows on asset prices by employing a panel VAR model. The empirical results suggest that capital inflows indeed contributed to the asset price appreciation in emerging Asian economies, although capital inflows shocks explain a relatively small part of asset price fluctuations. Positive

\footnotetext{
${ }^{14}$ See Kim, Kim, and Wang (2004) that capital flow shocks affect macroeconomic condition significantly in 1990s. 
capital flow shocks increase stock prices immediately and land prices with some delays. They also appreciate the nominal and real exchange rates.

\section{References}

Agenor, P. and A. Hoffmaister. 1998. “Capital Inflows and the Real Exchange Rate: Analytical Framework and Econometric Evidence.” In R. Glick ed. Managing Capital Flows and Exchange Rates. Cambridge University Press.

Albuquerque, R., 2003, “The Composition of International Capital Flows: Risk Sharing through Foreign Direct Investment,” Journal of International Economics, Vol. 61, Issue 2, pp 353-383.

Bernanke, B. S. and M. Gertler, 1999, “Monetary Policy and Asset Volatility,” Federal Reserve Bank of Kansas City Economic Review, vol 84, no.4, 17-52.

Bernanke, B. S. and M. Gertler, 2001, “Should Central Bank Respond to Movements in Asset Prices?’ American Economic Review, 253-257.

Bordo, M. and O. Jeanne, 2002, “Monetary Policy and Asset Prices: Does Benign Neglect Make Sense?” International Finance 5, 139-164.

Borio, C. and P. Lowe, 2002, “Asset Prices, Financial and Monetary stability: Exploring the Nexus,” BIS working papers no 114.

Caballero, R. and A. Krishnamurthy. 2006. Bubbles and Capital Flow Volatility: Causes and Risk management. Journal of Monetary Economics 53: 35-53.

Cecchetti, S. G, H. Genberg, and S. Wadhwani, 2002, “Asset Prices in a Flexible Inflation Targeting Framework,” NBER working paper No. 8970.

Christiano, L., Eichenbaum, M., Evans, C., 1999. Monetary policy shocks: What have we learned and to what end? In: Taylor, J.B., Woodford, M (Eds.), Handbook of Macroeconomics, Vol. 1A, North-Holland, Amsterdam, pp. 65-148.

Corbo, V., and L. Hernandez, 1996, "Macroeconomic Adjustment to Capital Inflows: Latin American Style versus East Asian Style,” Policy Research Working Paper 1377, IMF. 
Corsetti, G, P. Pesenti, and N. Roubini, 1999,"What Caused the Asian Currency and Financial Crisis?” Japan and the World Economy 305-373

Duttagupta, R. Fernandez, G., and Karacadag, C., 2005, Moving to a Flexible Exchange Rate: How, When, and How Fast? Economic Issues 38, International Monetary Fund.

Eichengreen, B., 1999, “Kicking the Habit: Moving from Pegged Rates to Greater Exchange Rate Flexibility,” Economic Journal 109, Conference Papers, pp C1-C14.

Eichengreen, B., and O. Choudry, 2005, "Managing Capital Inflows: Eastern Europe in an Asian Mirror," prepared for the Turkish Central Bank/Center for European Integration Studies conference on Macroeconomic Policies for EU Accession, Ankara, 6-7 May 2005, available at http://www.econ.berkeley.edu/ eichengr/research.html.

Filardo A. J., 2004,” Monetary Policy and Asset Price Bubbles: Calibrating the Monetary Policy Trade-offs, BIS working paper No. 155.

Froot, K.A., O’Connell, P.G.J., and Seasholes, M.S., 2001, “The Portfolio Flows of International Investors,” Journal of Financial Economics 59, pp 151-193.

Jansen, W.J., 2003, “What Do Capital Inflows Do? Dissecting the Transmission Mechanism for Thailand, 1980-1996,” Journal of Macroeconomics 25, 457-480.

Kim, S., 1999, "Do Monetary Policy Shocks Matter in the G-7 Countries? Using Common Identifying Assumptions about Monetary Policy across Countries,” Journal of International Economics 48 (2), 387-412.

Kim, S., Roubini, N., 2000, “Exchange Rate Anomalies in the Industrial Countries: A Solution with a Structural VAR Approach,” Journal of monetary Economics 45, 561-586.

Kim, S., Kim, S.H., and Wang, Y., 2004, "Macroeconomic Effects of Capital Account Liberalization: The Case of Korea,” Review of Development Economics 8 (4), 634-649.

Krugman, P., 1998, What's Happened in Asia, mimeo

Gilchrist, S. and J. V. Leahy, 2002, “Monetary Policy and Asset Prices,” Journal of Monetary Economics, vol 49, 75-97. 
Goodfriend, M., 2003, “Interest Rate Policy should not React Directly to Asset Prices,” in Hunter, W. G. Kaufman and M. Pomerleano, ed. Asset Price Bubbles: The Implications for Monetary, Regulatory, and International Policy, MIT press.

Gochoco-Bautista, M. S., 2007, “Asset Prices and Monetary Policy: Booms and Fat Tails in East Asia,” BIS working paper forthcoming.

Lipsey, R. E., 1999, “Role of Foreign Direct Investment in International Capital Flows,” NBER Working Paper no W7094.

Maqud, N., and C.M., Reinhart, “Capital Controls: An Evaluation,” NBER Working Paper No. 11973.

Mishikin, F. S. 1999,” Lessons from the Asian Crisis,” Journal of International Monetary and Finance, 18 (4): 709-723.

Mishkin, F. S., 2001, ”The Transmission Mechanism and the Role of Asset Prices in Monetary Policy,” NBER working paper No.8617.

Montiel, P.J. 1996. "Policy Responses to Surges in Capital Flows: Issues and Lessons.” In G.A. Calvo, M. Goldstein, and E. Hochreiter eds. Private Capital Flows to Emerging Markets After the Mexican Crisis. Washington, D.C.: Institute for International Economics.

Ogawa, E. and Yang D.Y., 2008, "The Dilemma of Exchange Rate Arrangements in East Asia,” Japan and the World Economy, vol 20, pp217-235.

Roubini N., 2006, “Why Central Banks should Burst Bubbles.” International Finance 9:1 87-107.

Sachs, Jeffrey D. and Wing Woo, 2000, “Understanding the Asian Crisis,” in Jeffrey D. Sachs and Klaus Schwab ed., The Asian Financial Crisis: Lessons for a Resilient Asia, MIT Press.

Schwartz, A. J., 2002,” Asset Price Inflation and Monetary Policy,” NBER working paper No. 9321.

Sims, C.A., 1980, Macroeconomics and Reality, Econometrica 48, 1-48.

Sims, C.A., 1988, Bayesian Skepticism on Unit Root Econometrics, Journal of Economic Dynamics and Control 12,463-474.

Sims, C. A., H., Uhlig, 1991. Understanding unit rooters: A helicopter tour. Econometrica 59, 1591- 
1599.

Sims, C.A. and T. Zha, 2006a, “Does Monetary Policy Generate Recessions?” Macroeconomic Dynamics 10,231-272.

Tirole, J. 1985. Asset Bubbles and Overlapping Generations. Econometrica Vol. 53, no 5: 10711100.

Ventura, J., 2002. Bubbles and Capital Flows. NBER working paper 9304.

White, W., 2006, “Is Price Stability Enough?” BIS working paper No. 205 
Table 1: Change in Foreign Reserve (\% per year)

\begin{tabular}{|l|l|l|l|l|l|l|l|l|}
\hline & 1999 & 2000 & 2001 & 2002 & 2003 & 2004 & 2005 & 2006 \\
\hline Indonesia & 16.4 & 7.8 & -4.4 & 13.7 & 12.9 & 0.0 & -5.6 & 24.1 \\
\hline Malaysia & 19.7 & -7.4 & 4.2 & 13.0 & 31.4 & 50.3 & 6.0 & 17.6 \\
\hline Philippines & 43.1 & -1.4 & 2.9 & -1.1 & 2.4 & -3.9 & 21.4 & 25.7 \\
\hline Thailand & 18.2 & -6.0 & 1.1 & 17.6 & 8.0 & 18.5 & 4.2 & 28.8 \\
\hline Korea & 42.4 & 29.9 & 6.9 & 18.1 & 28.0 & 28.2 & 5.7 & 13.6 \\
\hline PRC & 5.7 & 6.7 & 28.1 & 35.0 & 40.2 & 50.6 & 33.7 & 30.1 \\
\hline
\end{tabular}

Source: International Financial Statistics, International Monetary Fund

Table 2: Change in Monetary Supply (M2) (\% per year)

\begin{tabular}{|l|l|l|l|l|l|l|l|l|}
\hline & 1999 & 2000 & 2001 & 2002 & 2003 & 2004 & 2005 & 2006 \\
\hline Indonesia & 11.9 & 15.6 & 13.0 & 4.7 & 8.1 & 8.1 & 16.4 & 14.9 \\
\hline Malaysia & 13.7 & 5.2 & 2.2 & 5.8 & 11.1 & 25.4 & 15.4 & 16.6 \\
\hline Philippines & 19.3 & 4.8 & 6.9 & 21.0 & 4.2 & 10.2 & 10.3 & 21.4 \\
\hline Thailand & 2.2 & 3.7 & 4.2 & 2.6 & 4.9 & 5.4 & 8.2 & 6.0 \\
\hline Korea & 5.1 & 5.2 & 8.1 & 14.0 & 3.0 & 6.3 & 7.0 & 12.5 \\
\hline PRC & 14.7 & 15.4 & 14.4 & 16.9 & 19.6 & 14.5 & 16.7 & 16.9 \\
\hline
\end{tabular}

Source: Asian Development Outlook, Asian Development Bank

Table 3: Forecast Error Variance Decomposition of Asset Prices

\begin{tabular}{|l|l|l|l|l|}
\hline & \multicolumn{2}{|l|}{ Contribution of Capital Inflows Shocks } & \multicolumn{2}{l|}{ Contribution of Portfolio Inflows Shocks } \\
\hline & Stock Price & Land Price & Stock Price & Land Price \\
\hline 1 quarter & $5.5(3.8)$ & $3.5(2.9)$ & $1.8(2.0)$ & $0.9(1.1)$ \\
\hline 2 quarter & $4.5(3.5)$ & $4.1(3.7)$ & $1.9(2.0)$ & $1.5(1.8)$ \\
\hline 4 quarter & $6.5(4.8)$ & $8.8(7.0)$ & $3.0(2.9)$ & $2.7(3.0)$ \\
\hline 8 quarter & $7.8(6.0)$ & $19.8(12.5)$ & $4.1(3.9)$ & $5.5(5.3)$ \\
\hline
\end{tabular}






Source: International Financial Statistics, IMF

$<$ Figure 2> Trends of Gross Capital Inflows in Emerging Asian Economies

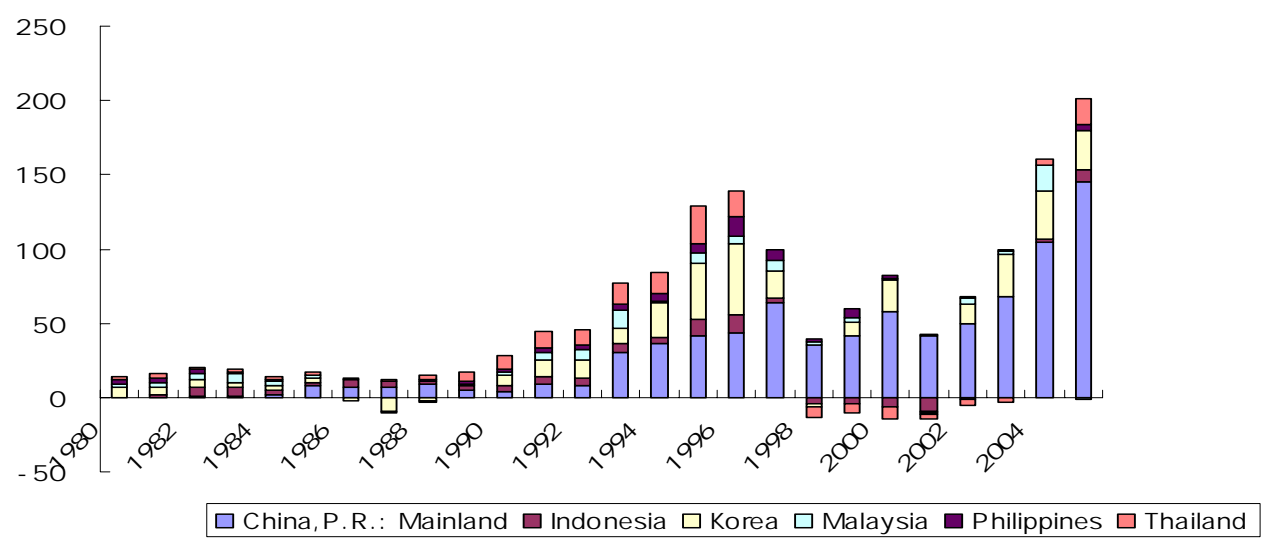

Source: International Financial Statistics, IMF

$<$ Figure 3> Patterns of Gross Capital inflows in Emerging Asian Economies

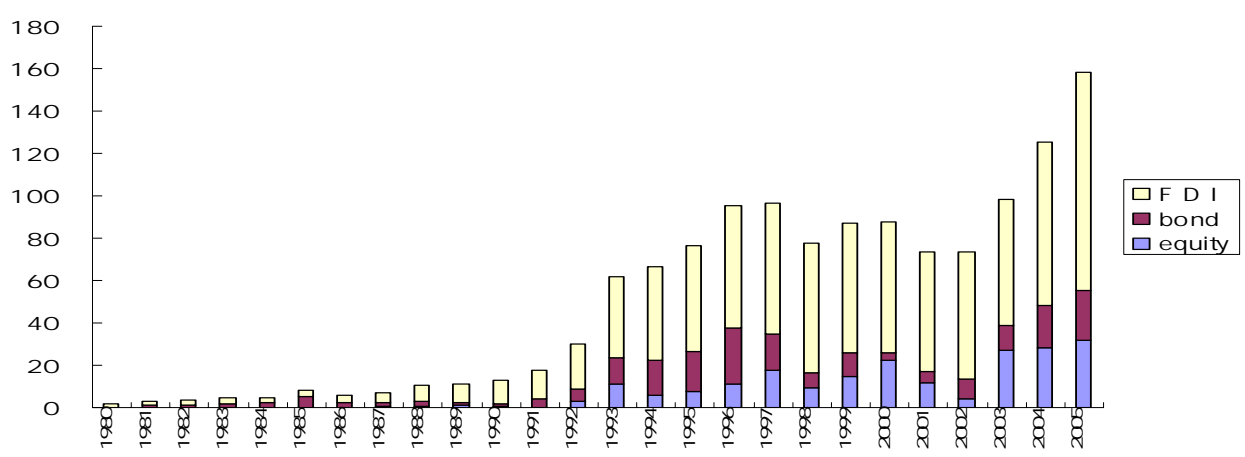

Source: International Financial Statistics, IMF

$<$ Figure 4> Trends of Gross Capital Outflows in Emerging Asian Economies

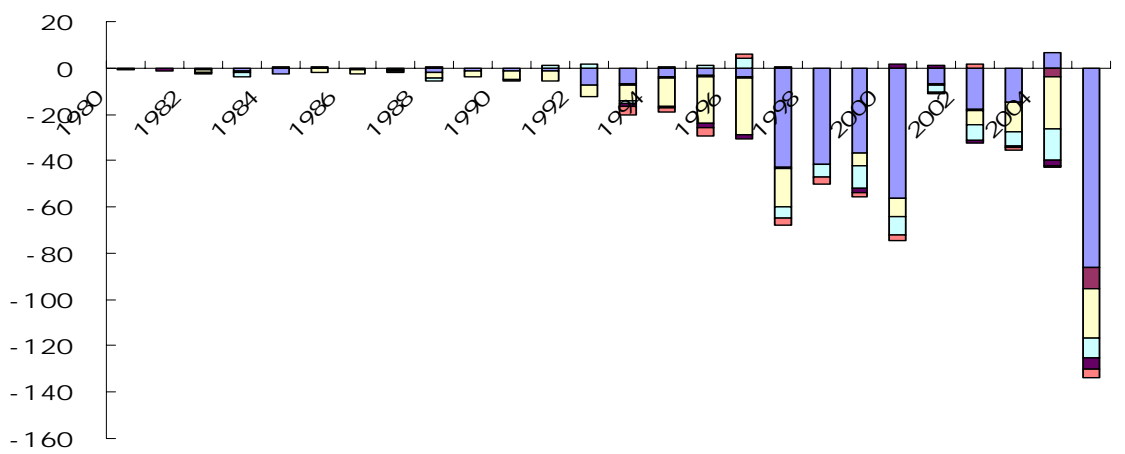

$\square$ China,P.R.: Mainland $\square$ Indonesia $\square$ Korea $\square$ Malaysia $\square$ Philippines $\square$ Thailand

Source: International Financial Statistics, IMF

$<$ Figure 5> Patterns of Capital outflows in Emerging Asian Economies 


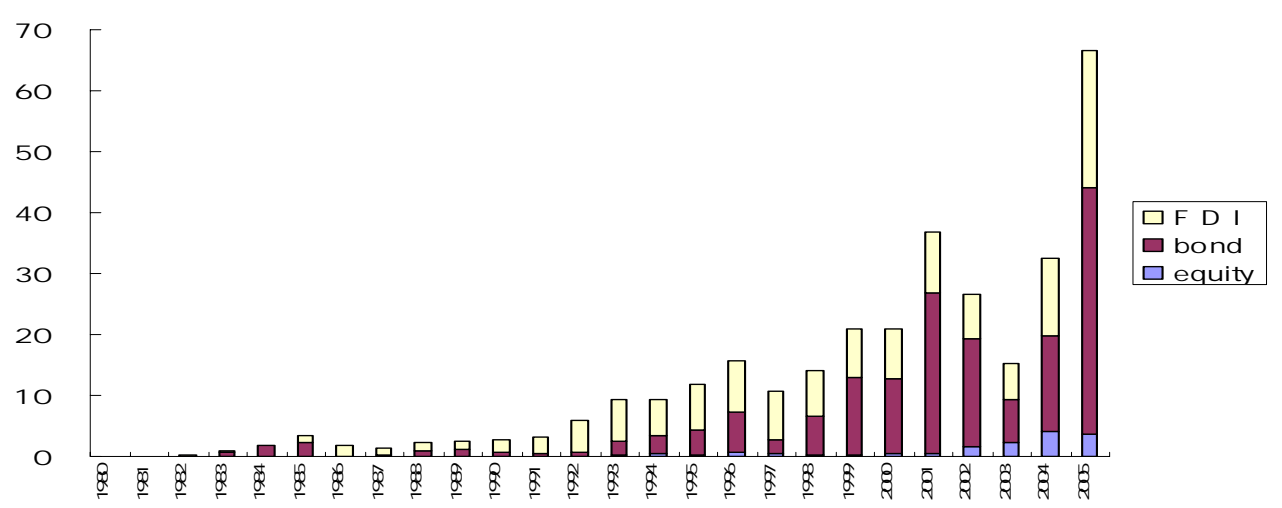

Source: International Financial Statistics, IMF

< Figure 6> Composite Stock Price Indexes: ASEAN-4, PRC, and Korea ${ }^{1}$



Source: Bloomberg

$<$ Figure 7> 10-year government Bond Yields

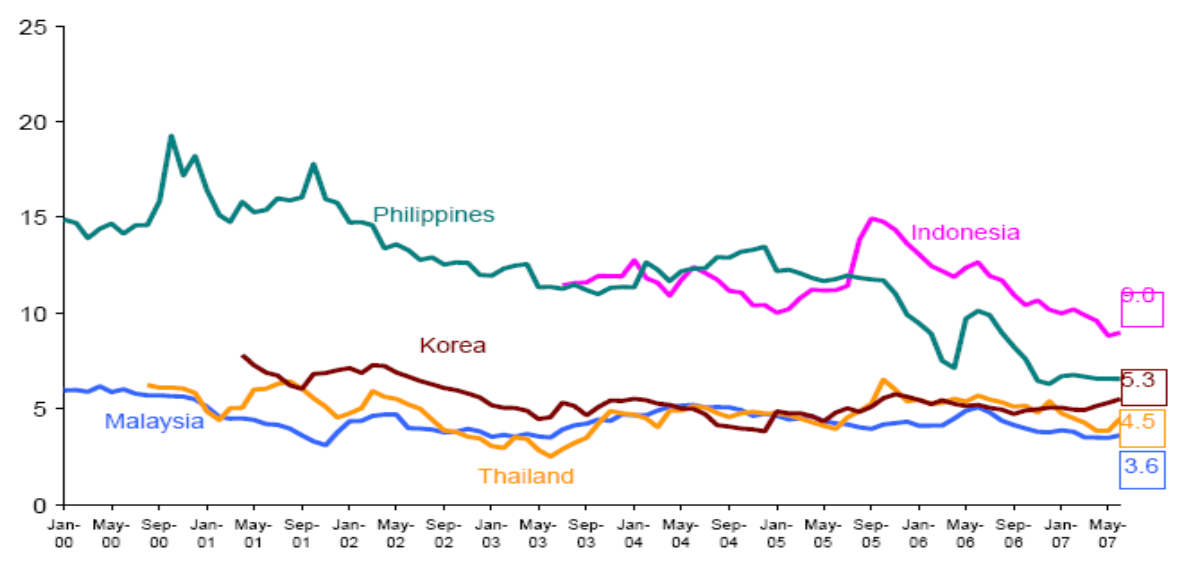

Source: Bloomberg 


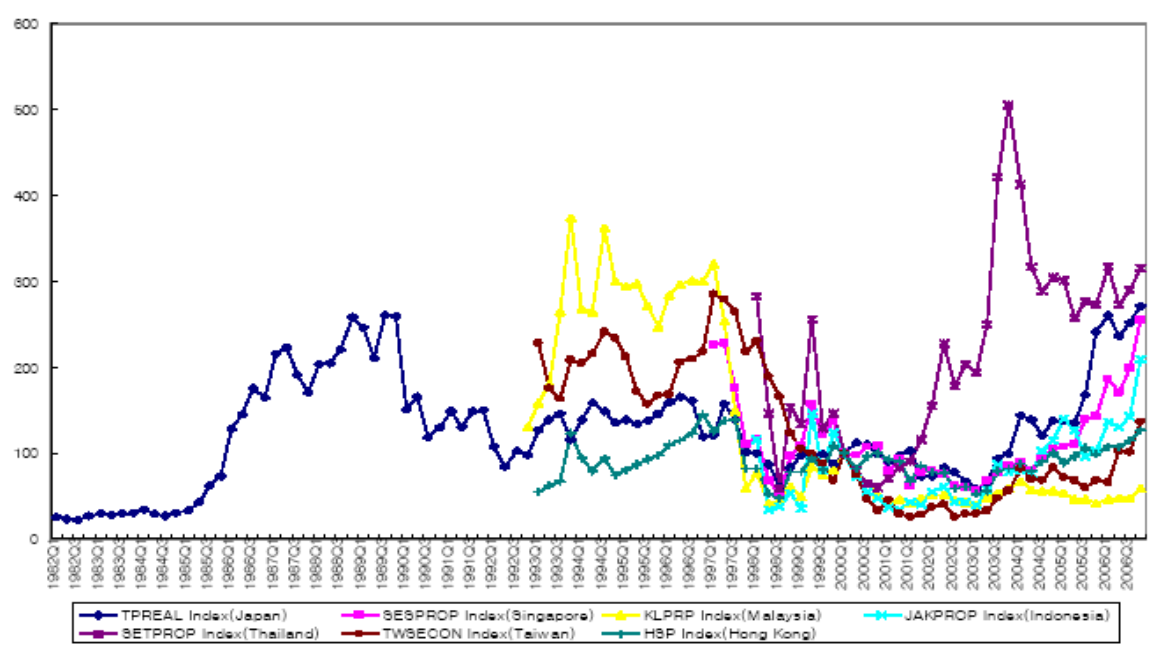

Source: Bloomberg

<Figure 9> Nominal Effective Exchange Rate ${ }^{1,2}$



$<$ Figure 10 $>$ Real Effective Exchange Rate ${ }^{1,2}$

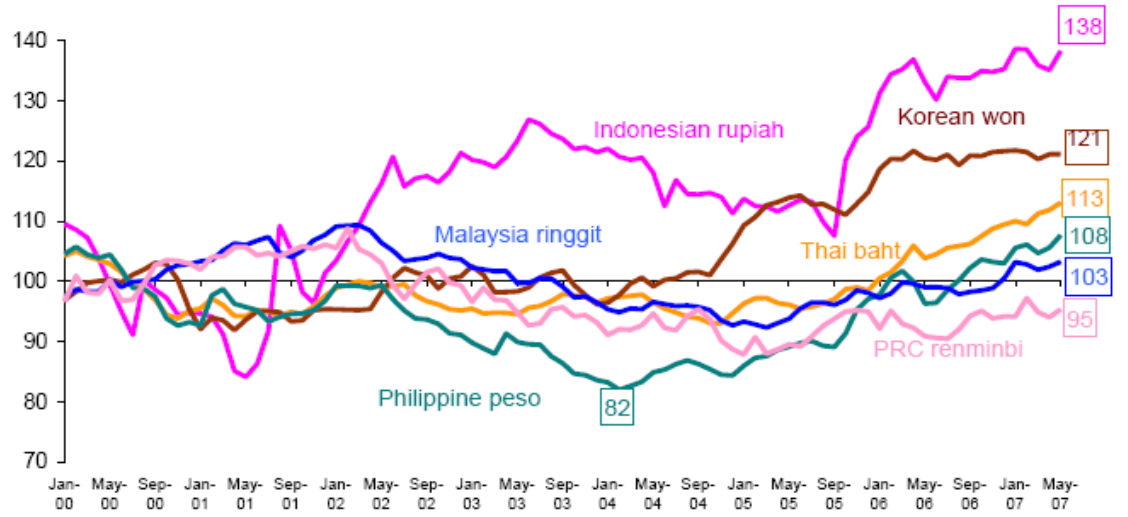

${ }^{1}$ Weighted average of a basket of 51 bilateral exchange rates adjusted by relative consumer prices. The weights are derived from manufacturing trade flows. ${ }^{2} \mathrm{~A}, \mathrm{n}$ increase is an appreciation.

Source: Bank for International Settlements. 
<Figure 11> Impulse Responses: Basic Model with Capital Inflows
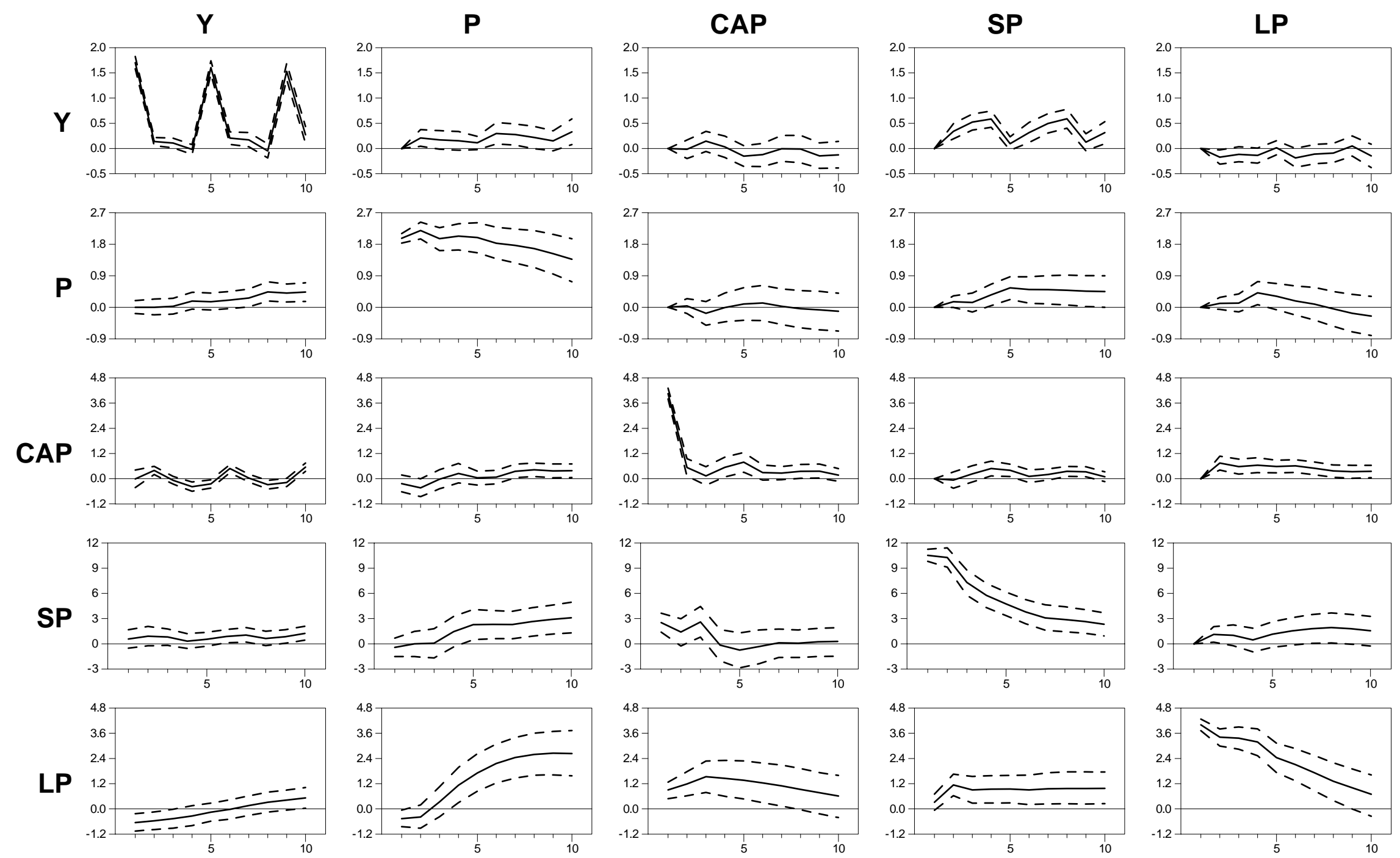
<Figure 12> Impulse Responses: Basic Model with Portfolio Inflows
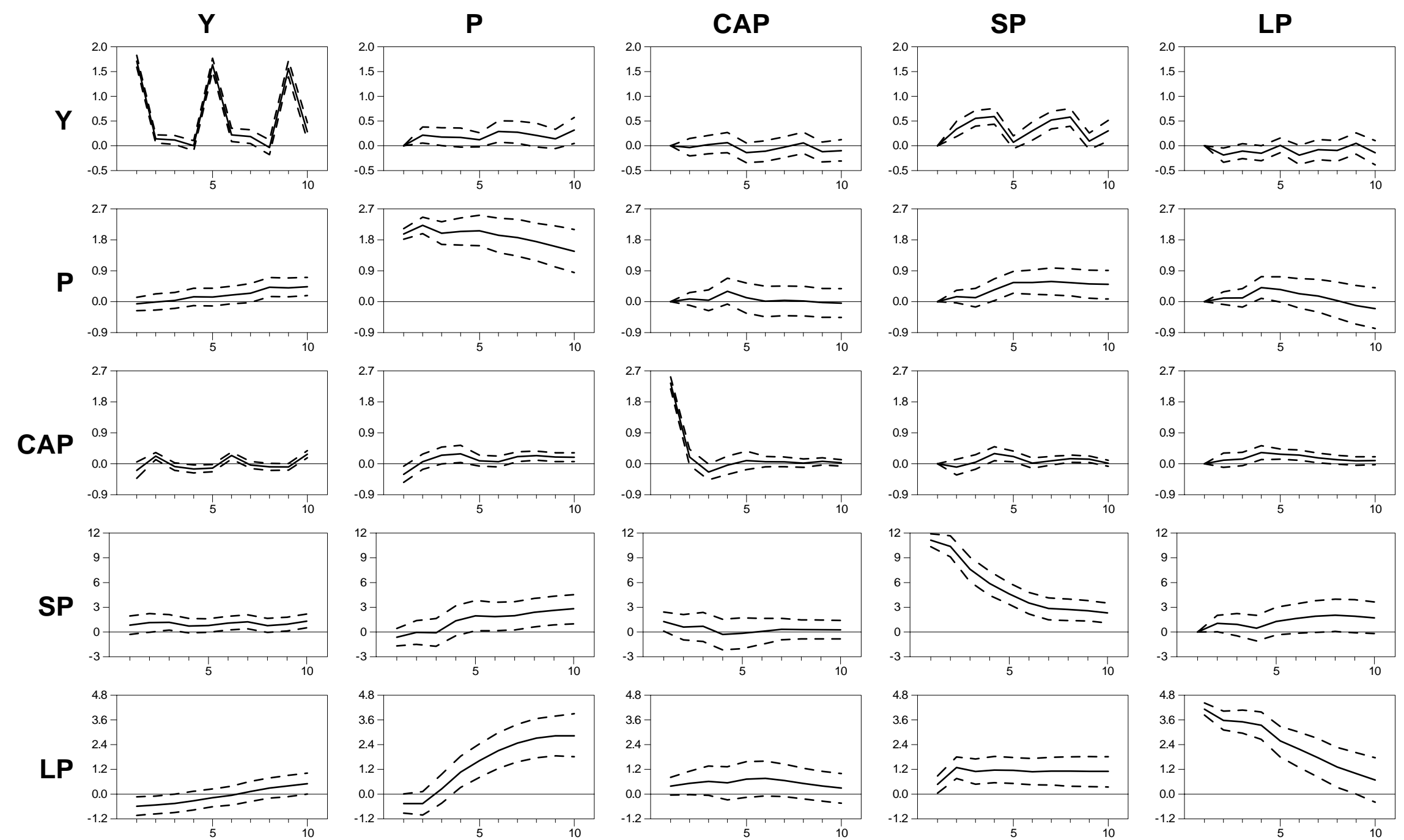
<Figure 13> Impulse Responses to Capital Inflows Shocks and Portfolio Inflows Shocks: Models with Short-Term Interest Rates or Outflows
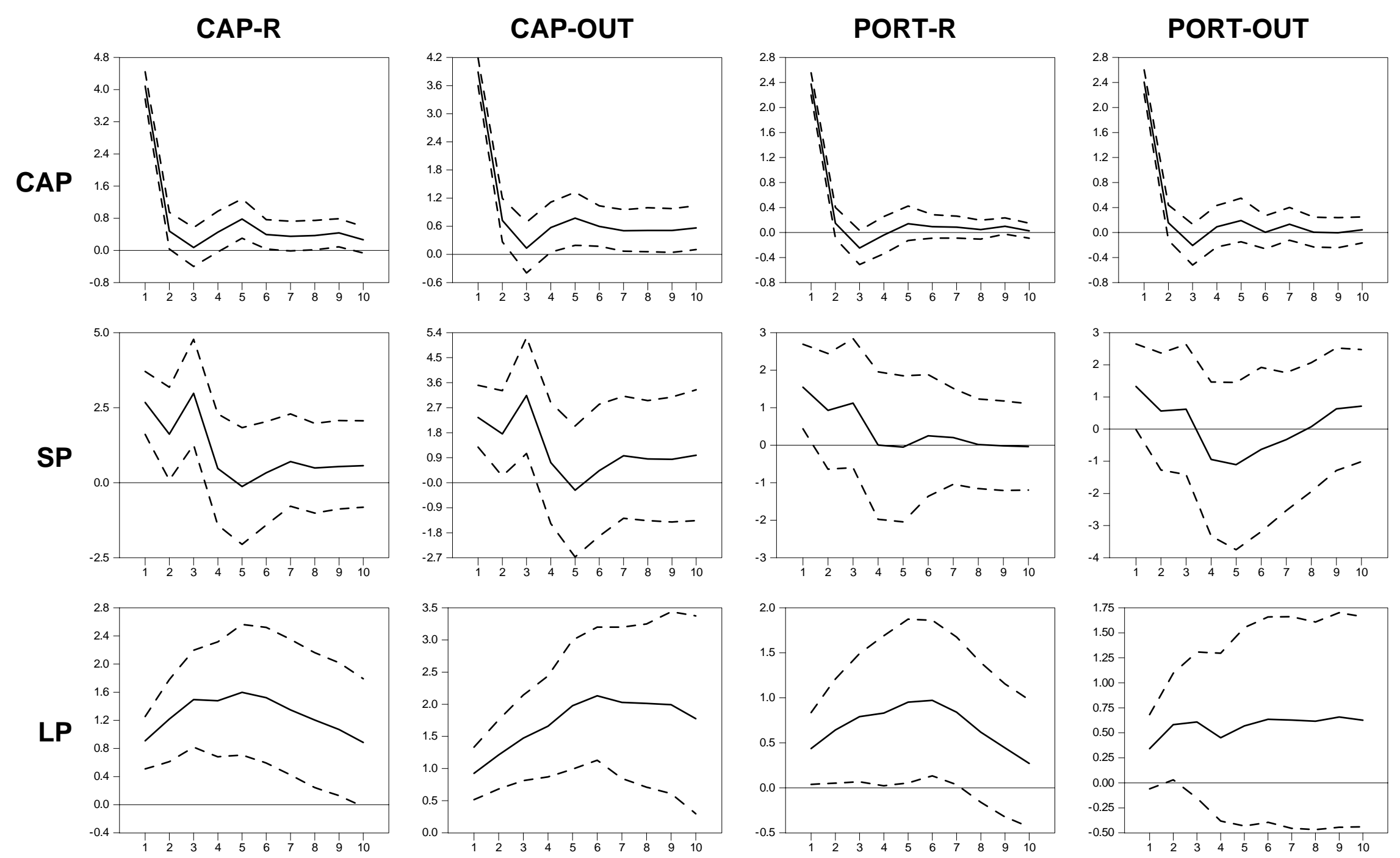
<Figure 14> Impulse Responses of Nominal and Real Effective Exchange Rates to Capital Inflows Shocks and Portfolio Inflows Shocks
